\title{
EFFECT OF HUMAN RESOURCE PRACTICES ON EMPLOYEES' BEHAVIOURAL OUTCOME IN NLC INDIA LTD
}

\author{
S. DHIVYA BHARATHI \\ Roll No: 1511040012 \\ Ph.D. Research Scholar (Full Time) \\ Department of Business Administration \\ Annamalai University
}

\author{
Dr. K. SUJATHA \\ Associate Professor \\ Department of Business Administration \\ Annamalai University
}

\begin{abstract}
Human Resource is the important strength for any organization in achieving competitive circumstances. Governing the human resources is very challenging as compared to managing technology or capital and for its successful administration, company requires effective HRM structure. There are various research is conducted on human resource practices in various companies with different HR aspects but studies relating to employees' behavioural outcome are not studied especially in public sector concern. The researcher framed a conceptual framework and the present study was conducted on "effect of human resource practices on employees' behavioural outcome in NLC India Ltd". The study focuses on various Dimensions of HR Practices and it is categorized as independent variable. Dimensions of HR practices are ability/skill practices, motivational practices and opportunities to participate in practices. The Descriptive research design has been adopted and it fulfills the objectives of the present study. The data collected from the employees of NLC India Limited. The researcher approached sample of 700 respondents. Among them 600 respondents were considered to be fit for further analysis. Hence the sample 600 is considered for the research. ANOVA, t-test, multiple regression, path analysis is used to describe relationship between variables. Hence the results showed that the HR practices influences employees behavioural outcome.
\end{abstract}




\title{
GREEN HRM PRACTICES AND ITS IMPLEMENTATION IN SELECT INDUSTRIES
}

\section{SATHYA}

Roll No: 1611040008

Ph.D. Research Scholar (Full Time)

Department of Business Administration

Annamalai University

\section{Dr. J. JAYAKRISHNAN}

\author{
Professor \\ Department of Business Administration \\ Annamalai University
}

\begin{abstract}
This research aimed to analysis the green HRM practices and its implementation in cement industry. Green human resource management has become a key business strategy for the present eco-friendly environment and global warming environment. Human resource department has playing an effective role for making the office as green. This research focuses on various green human resource practices implemented by the cement industry in Tamil Nadu.

The green human resource management practices will become important driver for environment sustainability within the organization by aligning its practices and policies with organizational sustainability goal reflecting towards eco-focus (Jain, 2015). Hence, how these activities are implemented in the cement industry is analysed in this research.

Descriptive research design is used. Pilot study is conducted among the 50 sample respondents in order to determine the responses rate. Based on the pilot study, reliability analysis is applied to find out the reliability of the tool for this population. The required sample size is determined using scientific formula. Samples of 488 respondents are considered for this study. In order to examine the relationship between independent variables and dependent variable, suitable statistical tools are applied.

The study on green human resource management is a need for more research on consolidation of the divergent streams of human resource management and environmental management to achieve the goal of environmental sustainability. Empirically testing the relationship of green human resource management with organization environmental performance adds to the understanding the concept of green practices and its consequences.

This study has analysed the green human resource practices and its implementation in Cement Industry environmental performance. It is found that green human resource practices has been with environmental performance. This study found that green human resource can adopt various green factors and practices in different Human Resource concerns like green human resource planning, induction, training, performance management, reward management and better industry relations which will have overall achievement of organisation goal. Human resource professionals face a lot of challenges regarding green HRM. However, it is clear from the study that the human resource professionals haves addressed the environmental needs in crafting human resource strategies and implementing the HR policies and practices in alignment with environment management.
\end{abstract}

Keywords : Green human resource planning, Green recruitment, Green job design, Green selection, Green intuition, Green training development, Green employee discipline, Green health and safety, Green employee relation, Green internal orientation, Green perforation evaluation, Green Environmental performance. 